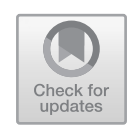

\title{
World War Two and Nazi Forays into the Killing of Civilians
}

On 1 September 1939, the Wehrmacht invaded Poland, an act that initiated French and British declarations of war, and thus signaled the start of World War Two. With their massive numbers, superior weaponry, and Blitzkrieg tactics, the Wehrmacht quickly swept Polish defenders aside. Then, on 17 September, the Soviets attacked Poland from the east. As anticipated, the Polish civilian population fiercely resisted the Germans, typically in the form of sniper attacks. The Wehrmacht's usual wartime policy in dealing with civilian resistance was twofold. First, captured resisters were tried in a military court and if found guilty, executed. Second, if resisters evaded capture, community leaders were taken hostage and their lives threatened if the partisan activity continued. ${ }^{1}$ However, on 3 September Himmler provided the German armed forces with a third and much swifter option: a shoot-to-kill authorization that allowed for the circumvention of a military trial. ${ }^{2}$ Some members of the German armed forces interpreted the authorization as a right to kill whomever and whenever they wanted; indeed, this is what it was. Armed with such powers, sectors of the Einsatzgruppen occasionally engaged in mob-like violence, acts which greatly concerned the Wehrmacht Commander-in-Chief Walther von Brauchitsch. ${ }^{3}$ Brauchitsch was so angry that on 21 September Himmler had to send Heydrich to personally smooth matters over with the powerful chief commander. Brauchitsch demanded one thing, the removal of Himmler's shoot-tokill order. In fear of having pushed influential figures in the Wehrmacht too far too soon, a few days later Himmler granted Brauchitsch's https://doi.org/10.1007/978-3-319-97999-1_3 
request. ${ }^{4}$ Although Brauchitsch's resistance signaled to the Nazi leadership that some of the Wehrmacht's top brass was unwilling to flaunt international military law, they also noticed that some were. ${ }^{5}$

By early October, only five weeks into the campaign, Poland conceded defeat. Soon thereafter, the Germans divided their half of the new territory into two: a western section, which they called the Incorporated Territory (annexed into Germany), and an eastern section called the General Government (a semi-independent zone occupied by Germany and governed by Nazi lawyer Hans Frank). Germany's rapid expansion had, however, exposed a flaw in Eichmann's emigration model for dealing with the "Jewish problem": The more nations the Wehrmacht conquered, the more Jews Germany inherited. There were 3 million Polish Jews, ${ }^{6}$ of which 600,000 to 700,000 lived in the now German Incorporated Territory. These numbers do not include the 18 million Christian Poles that the Nazi leadership would have to uproot when the time came to make room for in-coming ethnic German settlers. Before the new German/Soviet border tightened, the Germans tried to push as many of the unwanted Poles into the new Soviet territory. However, this was no long-term solution; it was only a matter of time before the Soviet authorities found out.

Eventually, the Nazi leadership decided to expel Poles from the Incorporated Territory and force them into the General Government. Polish Jews were to be sent to a reservation located near the General Government township of Nisko (in the eastern Lublin district). In an eager attempt to impress his superiors, on 17 October 1939 Eichmann tried to deport 912 Austrian Jews by train to the Nisko reservation. However, this attempt at mass deportation proved to be a more difficult exercise than he anticipated. Complicating issues included the higher priority authorities placed on housing the influx of ethnic German settlers over relocating German Jews, along with other economic and logistical issues. ${ }^{7}$ Amid the ensuing chaos, Eichmann's display of initiative backfired and, as a result, most of the Jews were returned to Austria. ${ }^{8}$ The problem of the Polish Jews remained, but soon after Heydrich announced a new policy: "in order to have a better possibility of control and later deportation," Polish Jews across both the Incorporated Territory and General Government were to be concentrated in designated ghettos in all the major Polish cities. ${ }^{9}$ Implementation of this interim solution took place in 1940. Meanwhile, from early to mid1940, Arthur Greiser (Governor of the Wartheland, a province within 
the Incorporated Territory) boasted in Nazi circles of his desire to render his fiefdom judenfrei ("free of Jews"). To fulfill this desire, Greiser requested Hans Frank in the more eastern General Government to accept a few hundred thousand Wartheland Jews. Frank, who also one day hoped to make the same claim about his territory, balked at Greiser's demand. Adding to the ongoing complexities of what exactly was to be done with the Jews, Frank did not want his fiefdom to become a dumping ground for others' unwanted peoples. ${ }^{10}$

Once secured in the Polish ghettos, there remained much debate over where to relocate all of these Jews. The realist Nazi bureaucrats identified a few potential locations, the most popular of which became possible with the successful spring 1940 conquests of Denmark, Norway, Holland, Belgium, Luxemburg, and France. Jews were to be deported by ship to the island of Madagascar, a French colony off the south eastern coast of Africa. ${ }^{11}$ According to Himmler, on 25 May, "The Führer read the six pages (of the plan) through and found them very good and correct..."12 Despite his strong threats, Hitler again revealed he was a realist. And, as Browning observes,

This episode is of singular importance in that it is the only firsthand account by a high-ranking participant-Himmler-of just how a Hitler decision was reached and a Fübrerbefehl, or Hitler order, was given in respect to Nazi racial policy during this period. The initiative came from Himmler. However, he did not present Hitler with a precise plan; it was rather a statement of intent, a set of policy objectives. The details of implementation would be left to Himmler. Hitler indicated both his enthusiastic agreement and the men with whom the information could be shared [...] He simply allowed it to be known what he wanted or approved. ${ }^{13}$

Kershaw agrees: When it came to the Jews, Hitler set a "vicious tone" then sanctioned and legitimated what he sensed were his underling's best-most realistically achievable-initiatives. ${ }^{14}$ However, access to Madagascar required naval dominance over Britain, something the Germans never achieved. Consequently, the Madagascar Plan was shelved pending a victory that never arrived. The Madagascar Plan might then have been the most realistic option, but as this solution stalled, Hitler went on to drop hints of his openness to supporting any solution, no matter how radical: 
Typical of Hitler's stance was his wish, expressed towards the end of 1940, that his Gauleiter in the East should be accorded the 'necessary freedom of movement', to accomplish their difficult task, that he would demand from his Gauleiter after 10 years only the single announcement that their territories were purely German, and would not enquire about the methods used to bring this about. ${ }^{15}$

The message was clear: Most important for Hitler was that the Jewish problem be solved; he did not care how they got there.

One benefit stemming from the Nazi's spate of military victories was that instead of funding their wars by shouldering more national debts or leveling unpopular taxes on the German public, they started financing subsequent military campaigns by plundering the economies of those they conquered. ${ }^{16}$ Consider, for example, France, who through increasing occupation fees ended up paying the Nazis about 900 billion francs ${ }^{17}$ - money then invested into Hitler's plans for eastern expansion. But why did so many Germans support these acts of state larceny? There are probably several overlapping reasons. First, the Nazi regime made sure that every class of German both at home and abroad personally benefited from Hitler's military ambitions. For example, the Nazis used some of the occupation fees to increase their soldiers' wages. ${ }^{18}$ With more money in their pockets, the soldiers were then encouraged by both the regime and their families to purchase consumer items from the occupied territories and-to the detriment of the local economies and food supply - send their purchases back home. Herein lies the reason why between 1939 and 1945 Germany enjoyed the highest standard of living of any European nation in the war. ${ }^{19}$ As we shall see, this other form of Nazi welfare only drew the average German-who Aly describes as a "well-fed parasite..." — _ a little further into turning a blind eye to some of the regime's subsequent and even more unethical criminal ventures. A second reason for supporting the Nazi's illegal occupation practices was that the soldiers' purchases were preserved by a facade of legality: The men did (at least initially) not steal but paid for all their consumer items. ${ }^{21}$ This, however, did not stop some Germans from sensing an injustice in their rising purchasing power. Consider, for example, the famous postwar writer and then Wehrmacht conscript Heinrich Böll who, despite the legal veneer surrounding his purchases, detected something unethical in his shopping sprees. In a letter dated September 1940 to his family back in Germany, Böll conceded: 
The store shelves will of course now be emptied by soldiers... I have reservations about joining in the stockpiling; although everything is paid for, it reminds me of robbing a corpse. ${ }^{22}$

But it was Hitler who, a few months into the start of World War Two, perhaps best expressed a third reason why so many Germans repeatedly backed the Nazi's ever-descending ethical bar: "No one will ask questions, once we've achieved victory." 23 In other words, as Nazi power rose with each victory, Germans everywhere sensed-much like every compliant link across the Obedience studies - they could unethically participate in and personally benefit from the wider organizational system with probable impunity.

Spurred on by Germany's initial military success, as early as 31 July 1940 Hitler started seriously contemplating an attack on the Soviet Union. ${ }^{24}$ If indeed Hitler pursued this invasion, perhaps a territorial solution to the Jewish question could be found somewhere in the vast hinterlands of the Soviet Union. Around this time, the "Jewish question," however, was put aside in favor of tasks that demanded more immediate attention, such as the extraction of economic resources from the recently conquered Polish territories. One such venture involved an initially inconspicuous set of ex-army barracks near the Polish city of Krakow, which, during the spring of 1940, had been converted into a prison for German criminals and recalcitrant Poles. ${ }^{25}$ The Germans called the prison Auschwitz.

The strategic importance of what became known as Auschwitz I to the Nazi regime increased significantly after September 1940 when Oswald Pohl (Chief of the SS Main Administration and Economic Office) discerned in the surrounding area immense economic potential. ${ }^{26}$ Pohl's assessment was independently confirmed when officials from the German corporation IG Farben expressed an interest in the region's natural resources, centrally located railway junction, accompanying Nazi tax exemptions and, of course, access to cut-rate prison labor. On the downside, however, the area lacked any basic infrastructure.

On I March 1941, Himmler toured Auschwitz I with some IG Farben officials. To attract corporate investment, he promised to greatly increase the size of the fledgling camp's manual labor pool. Himmler ordered an expansion of Auschwitz I's capacity to 30,000 and the construction of a massive satellite camp nearby capable of holding 100,000 laborers. ${ }^{27}$ Himmler informed IG Farben officials that the 
laborers-drawn from the local Jewish and non-Jewish populationswould be tasked with building whatever infrastructure they desired. Himmler also likely had in mind a different and far more efficient source of slave labor. Even before he visited Auschwitz I, Himmler knew of Hitler's secret intention in the coming months to invade the Soviet Union. The anticipated swift victory would mean a sudden flood of Soviet POWs. Soviet POWs were a much more attractive source of slave labor than the local Polish population, because nearly all would be strong young men capable of arduous labor, whereas many Poles would come with families, including the young and old who would require housing and feeding for nothing in return. ${ }^{28}$

\section{The “Twisted Road” to “Realizing the Unthinkable”}

Between the end of 1939 and mid-1941, as realist Nazi bureaucrats debated where to send Jews and other conquered peoples, events of central importance to the subsequent attempt to exterminate European Jewry took place elsewhere. Ordinary and arguably only moderately antisemitic Germans, who, according to Hilberg, came from a "remarkable cross-section of the German population," 29 began demonstrating an uncanny ability to eliminate fairly large numbers of defenseless civilians using what became by the war's end the three most common killing methods: shooting, starvation, and gassing.

\section{Shooting}

During the invasion of Poland, as partisans did their best to resist the Nazi attack, the Wehrmacht were faced with orders to execute civilians - either those caught resisting or hostages taken in place of those still at large. A death sentence also awaited those on Heydrich's list of anti-German agitators. To kill all of these civilians, execution squad commanders employed the only method of killing unarmed people they knew-death by military-style firing squad. Victims were shot facing the shooting squad, separated by ten or so meters. For photographic evidence of these early military-style executions (September and October 1939), see https://rarehistoricalphotos.com/facing-death-six-polish-civilians-1939/ and https://www.ushmm.org/collections/the-museums-collections/ collections-highlights/german-invasion-of-poland-75-years-later/ from-the-museums-collections/execution-of-piotr-sosnowski. 
As discussed in Volume 1, firearms render killing psychologically easier for perpetrators than when using weapons like the bayonet. Guns make killing relatively easier for the same reason these weapons tend to reduce the pleasure sexually motivated serial killers experience when killing: Firearms ensure the deathblow/s to victims need not be felt thus reducing the displeasure that more ordinary (typically squeamish) people would otherwise experience if they tried to kill with more tactile means. As Levin and Fox observe:

Among serial murders that are sexually inspired, the use of a gun is, in fact, remarkably rare. For those killers, physical contact is so crucial to satisfying their murderous sexual impulses that a gun robs them of the pleasure they receive from killing with their hands. ${ }^{30}$

Firearms also make killing physically easier, because, compared to other closer-range weapons and methods, they generate the force behind the lethal blow. In sum, firearms are comparatively more lethal than other more common tactile weapons or methods of homicide, because, as Egger and Peters succinctly put it, "a gun requires considerably less proximity, strength, agility, skill and squeamishness, and offers less opportunity for self-defence..." "31 Furthermore, it should be remembered that as mass shootings in US educational institutions repeatedly illustrate, when it comes to raw power, concealability, and rapid fire, not all guns are equal.

Having said all this, firearms might make killing easier, but they do not make killing easy. Shooters are still likely to experience high levels of visual and perhaps even auditory perceptual stimulation - they directly see and hear the destructive consequences of pulling the trigger. In fact, as the number of Polish hostages increased-with three or even up to ten Poles executed for every German life lost ${ }^{32}$ - some execution squad members started experiencing what Lieutenant General Max Bock described as "vast agitation and powerful emotional stress..."33 Stress increased when shooting certain types of civilians-executing children was deemed a particularly repugnant task. ${ }^{34}$ During these early executions, victims collapsed where they were shot (as shown in both the above links to photographs). Afterward, if nobody else could be found, the squad members had to dig graves to dispose of the bodies. Doing so meant that the shooters then had to directly confront the horrific human consequences of their actions. According to Grossman, confronting a person one has just killed significantly accentuates the initial trauma, "since some of the psychological buffer created by a midrange kill disappears upon seeing the victim at close range." 35 
Although the German armed forces encountered some psychological difficulties when killing Poles in this way, they nevertheless managed to shoot approximately 16,000 civilians - about 5000 of whom were Jewish. ${ }^{36}$ Also, after the Poles conceded defeat, in the last months of 1939 the SS forces and ethnic German auxiliaries shot up to 50,000 members of the Polish intelligentsia and other civilian resisters (7000 of whom were Jewish). ${ }^{37}$

\section{Starvation}

Independent of Nazi officials in Berlin, local German authorities in the two largest Polish ghettos at Lódź (Incorporated Territory) and Warsaw (General Government)—which between them contained about one-third of all Polish Jews under Nazi control ${ }^{38}$ — decided at different times and for different reasons to seal off their ghettos from the adjacent non-Jewish communities. ${ }^{39}$ Cut off from outside help, the poorest Jewish prisoners began to perish from starvation and associated diseases. The destructive effects of these policies were first observed in the Lódź ghetto, which, with 163,177 Jews $^{40}$ crammed into a 2.6-square kilometer sector of the wider city, ${ }^{41}$ was sealed in April 1940. That summer Governor Greiser reported that from the "point of view of nutrition and the control of epidemics" life in the Lódź ghetto had already become untenable. ${ }^{42}$ Between June 1940 and the end of January 1941, more than 7000 Jews died in the Lódź ghetto. ${ }^{43}$

Alexander Palfinger, a German ghetto administrator, seized upon this catastrophe as a partial solution to the escalating "Jewish problem." As far as he was concerned, "A rapid dying out of the Jews is for us a matter of total indifference, if not to say desirable." According to Palfinger's interpretation of Nazi ideology, such an outcome was consistent with what he anticipated would become the regime's "radical course," because in relation to the "Jewish question the National Socialist idea...permits no compromise..."44 Palfinger thus provides another example of Carl Friedrich's rule of anticipated reactions (i.e., guessing what one's superior probably desires) or Browning's "seizing the initiative from below..."

Browning calls German ghetto administrators like Palfinger, who believed the Jews should be starved, "attritionists." 45 Opposed to attritionists were another group of administrators termed "productionists," who believed that sources of labor should not be wasted, and that making the Jews work would not only financially benefit Germany, but also enable Jews to obtain food at no cost to the Reich, thus averting any risk of starvation. This self-sustaining policy could be maintained until Berlin 
decided where to send these Jews. As Palfinger's immediate superior, Hans Biebow (Lódź's chief ghetto administrator), argued on 18 October 1940, "everything must be done to make the ghetto self-sustaining." 46 Biebow and his superior, Dr. Karl Marder (the deputy mayor of Lódź), set up a ghetto economy, indicating that in Lódź the "productionists" were in control and Palfinger was ignored. ${ }^{47}$

The discontented Palfinger soon transferred to the Warsaw ghetto, where by March 1941 nearly half a million Jews had been squeezed into just over three square kilometers of space. ${ }^{48}$ There he met like-minded "attritionists" Waldemar Schön and Karl Naumann, and together they generated conditions that promoted what Schön euphemistically termed "premature impoverishment..."49 But again Palfinger's intentions were subordinated to those of Warsaw's own "productionists" who dominated among the local German authorities. At a meeting on 3 April 1941, Walter Emmerich argued, "The starting point for all economic measures had to be the idea of maintaining the capacity of the Jews to live" [italics original]. ${ }^{50}$ Thus, on 19 April 1941 a new "productionist" policy was introduced in Warsaw. Schön was replaced by Max Bischof who was told that if Palfinger caused any further problems he could have him removed. Palfinger stopped trying to anticipate Hitler's desires and, having narrowly avoided dismissal, by early May 1941 informed a surprised Adam Czerniaków (the Jewish council chairman that helped manage the ghetto), "that he will do everything to improve the food supply." 1

Despite all this, because the Nazi regime struggled to meet the generous basic food requirements of its civilian population, ${ }^{52}$ being unable to always accommodate the needs of those at the top of their racial hierarchy meant that grueling times indeed lay ahead for the Jews at the bottom, irrespective of how hard they were willing to work. As Göring said, "If someone has to go hungry, it won't be the Germans..." 53 In the end, promises of more food were made to the Jews in the Polish ghettos, but, as Biebow pointed out in January 1941, little arrived because it was continually "withdrawn for allegedly more urgent needs." 54 People in the ghetto population received about 220 calories per day, which is about $15 \%$ of normal dietary requirements. ${ }^{55}$

During April and May 1941, a famine of endemic proportions took hold of the Warsaw ghetto killing 6000 Jews. ${ }^{56}$ Nevertheless, German administrators ("productionists" and "attritionists" alike) followed directives from Berlin that the Jews were not to leave the ghetto in search of food. ${ }^{57}$ These administrators were able to tolerate the deaths that resulted with relative psychological ease because, for reasons discussed in 
Volume 1, starvation as a method of killing causes little affective stimulation. None of the Germans involved-from those who rounded up and delivered victims to the ghettos, to the administrators, and the guards who prevented their escape-had to touch, see, or hear victims in their death throes. Excluding guards who frequently shot escapees, none of the perpetrators had to actually kill Jews. Instead, the German authorities were able to pass responsibility to a reified "Berlin" for imposing such deadly conditions. They did not perceive themselves as the most responsible for the deaths. This strain resolving displacement of responsibility was made possible by the division of labor inherent within the ghetto administration's bureaucracy, which helped ease the perpetrators' psychological burden of death.

Being in positions of power, most Germans involved could, if they so chose, deploy Obedience study-like avoidance techniques to circumvent the perceptual reality of those slowly dying in the ghettos. Consider, for example, Claude Lanzmann's conversation with Deputy Commissioner of the Warsaw ghetto, Franz Grassler: "Did you go into the ghetto? Seldom. When I had to visit Czerniaków. What were the conditions like? Awful. Yes, appalling. I never went back when I saw what it was like. Unless I had to. In the whole period I think I only went once or twice." 58 The reason Grassler rarely had to enter the ghetto was because the Nazis formed Jewish councils - the so-called Judenrat-and tasked them with organizing the day-to-day management and policing of the ghettos. Here, the Nazis deployed "the tried-and-tested colonial" technique "of indirect rule through favored natives who got privileges...in exchange for helping control everyone else." ${ }^{59}$ As we shall see, throughout World War Two the Nazis repeatedly relied on this divide and rule management technique. The Nazis did so because not only it more efficiently minimized German labor, but also it spread complicity for any harmful outcomes onto the Jewish leadership. As one German official in Warsaw noted, during periods of extreme hardship the ghetto inhabitants would rather conveniently "direct their resentment against the Jewish administrations and not against the German supervisors." ${ }^{60}$ And when the Nazi overlords did have to enter the ghettos, the desperate and corrupting conditions endured by the starving population only served to reinforce the former's prejudicial stereotypes of the Ostjuden (Eastern Jew). These distraught and starved people often looked and sometimes even behaved just like the parasitic and threatening criminals the Nazis assumed them to be. ${ }^{61}$ 


\section{Gassing}

As early as July 1933, the Nazi regime passed the Weimar Republic's Law for the Prevention of Genetically Damaged Offspring, after which somewhere between 200,000 and 350,000 Germans were sterilized. ${ }^{62}$ However, several years later in October 1939, congruent with Nazi ideology, Hitler produced the following secret document,

Berlin, I Sept. 1939

Reich Leader Bouhler and Dr. med. Brandt are charged with the responsibility of enlarging the competence of certain physicians, designated by name, so that patients who, on the basis of human judgment, are considered incurable, can be granted mercy death after a discerning diagnosis.

(signed) A. Hitler ${ }^{63}$

This document, which Hitler backdated to the start of the war, authorized what the Nazi's euphemistically termed the euthanasia program: the extermination of people with physical and mental disabilities. Hitler signed the document because chancellery officials informed him that the physicians approached to implement this policy would likely require an assurance from the state that they would not be held criminally liable for their harmful actions. ${ }^{64}$ That is, Hitler's advisors anticipated that those most directly involved would need to know that they could kill with impunity. Much like Milgram's decision to insert the strain resolving "Waver [sic] of responsibility" into his emerging procedure (see Volume 1), ${ }^{65}$ the chancellery officials also anticipated that their subordinate harm inflictors, fearing someone might later question them about their decision to hurt others, needed to feel they were sufficiently covered.

For several reasons, this is an important document. First, it illustrates that when Hitler suspected a policy of exterminating "subhumans" had a realistic chance of successful implementation, the strong believer in him was willing to pursue it. Second, his backdating of this document to the same date he instructed his Death's Head Units to start killing "all" members of the "Polish race" and when he threatened to start annihilating "the Jewish race in Europe" triangulates when in earnest Hitler intended to convert Nazi ideology into a reality. It was from I September 1939 that he wanted to start killing all "subhumans."66 The problem for Hitler was that his subordinates were not yet willing or capable of converting his intentions into a reality. Nevertheless, this 
document irrefutably connects Hitler to, and establishes him as, the leading instigator of Nazi genocidal ambitions, which (in conflict with his usual modus operandi) captures his direct top-down orders to kill.

Clearly, however, Hitler had confidence in the ability of Philipp Bouhler (from the private chancellery) and Karl Brandt (Hitler's private doctor) to set up an organization capable of converting his desire into a reality. In all likelihood, this confidence traces back to the fact that such killings would target a particularly powerless group segregated from wider society in secretive institutions. Furthermore, political resistance to this policy was unlikely because the wider German public would be distracted by the natural distress of a nation at war.

Bouhler and Brandt soon formed an organization called Tiergartenstraße 4 (T4). The organization started experimenting with different killing techniques, including lethal injection, which Brandt suspected T4 staff might willingly use on patients. However, he later concluded that this method was insufficiently "humane." 67 Trial-and-error exploration confirmed that lethal injection was too slow and unreliable. ${ }^{68}$ It surely didn't help that this method of killing necessitated a physical connection between the injector (cause) and injected (effect), especially when patients died slow and presumably painful deaths. Then, Viktor Brack from Hitler's private chancellery, in conjunction with chemist Albert Widmann, suggested diverting pure bottled carbon monoxide gas into a hermetically sealed room, ${ }^{69}$ intuiting that this was a method the T4 staff might use. Put differently, when compared to lethal injection, Brack and Widmann suspected the more "humane" method of gassing might better ensure the act of killing would remain within the T4 staff's Zone of Indifference - a task that, without reservation, they would willingly partake. This method of killing was trailed soon after the start of the war when the tentacles of the euthanasia program reached across Germany's border and into the annexed Polish territories. ${ }^{70}$

More specifically, in Poland Brandt helped set up the Lange Commando, headed by Herbert Lange, a "no-nonsense" fanatical Nazi. ${ }^{71}$ The 15-man strong commando was based in Fort VII, a recently established Gestapo prison located in Poznań (in Greiser's Wartheland province in the former Poland). ${ }^{72}$ Around October or November 1939, the T4 chemist August Becker arrived at Fort VII armed with cylinders of carbon monoxide. Becker was there to provide Lange with "technical assistance" in pursuit of an experimental killing operation. ${ }^{73}$ The Lange Commando locked a group of psychiatric patients in a prison cell that 
had rather hastily been hermetically sealed with clay. ${ }^{74}$ Carbon monoxide was then pumped into the cell, killing the patients. Throughout December, Lange and his men used this killing technique to exterminate patients from the surrounding area. They also instructed prisoners from Fort VII-non-Jewish Poles accused of partisan activity-to empty the cell and, in a nearby forest, bury the victims' bodies. ${ }^{75}$ After some reflection, Lange deemed collecting and then killing patients at Fort VII inefficient and soon after instructed his Polish prisoner work detail to help convert a truck with a large cargo cabin into a mobile gas chamber. ${ }^{76}$ Despite accounts that Lange had two or more of these early-model gas vans, Patrick Montague is confident that only one such truck existed. ${ }^{77}$ Canisters of pure carbon monoxide were attached to the driver's compartment. From January 1940, this truck was observed being driven to victims located at various institutions throughout the Wartheland. ${ }^{78}$ Once patients were locked in the cargo cabin, gas was released by opening valves located in the driver's cabin. Again, Lange's prison work detail was instructed to dispose of the victims' bodies in a nearby forest. Using Polish workers for such tasks obviously enabled Lange's men to avoid having to touch the recently killed victims.

Perhaps inspired by Lange's efforts, back in Germany around January 1940 a team of T4 officials were invited to Brandenburg-Havel prison to observe a demonstration. Twenty institutionalized men were locked in a cell $^{79}$ and according to Becker, having recently returned from his trip to Fort VII, the cell was,

a tiled shower room, measuring about three meters by five, and three meters high. On the periphery were benches, and along the wall, at about ten centimeters from the ground, a gas main about an inch in diameter passed. This pipe was pierced with little holes out of which the carbon monoxide came. ${ }^{80}$

A physician controlled a lever on the gas canister. After about twenty minutes, asphyxia set in followed by death. ${ }^{81}$ At least seventeen T4 officials observed this demonstration-including Brandt, Brack, Widmann, Philipp Bouhler, Christian Wirth, Irmfried Ebel, and August Becker-all of whom went on to play central roles in the extermination of Jews. ${ }^{82}$ They deemed the demonstration so "successful" that having discovered what they suspected was the "one best way" to achieving Hitler's goal of exterminating people with disabilities, the euthanasia gassing 
program was initiated in Germany. Five permanent gas chambers were set up at various institutions throughout Germany, including Grafeneck, Bernburg, Hadamar, Hartheim, and Sonnenstein. These institutions tended to have benign, strain resolving names such as The Charitable Foundation for Institutional Care and The Reich Work Cooperative for Institutional Care. ${ }^{83}$

Throughout the Wartheland between January and April 1940, Lange's roaming unit continued killing Poles with disabilities. ${ }^{84}$ The commando proved so effective that in May they were seconded to an East Prussian hospital (a few hundred kilometers north) where, across a mere two-week period, they gassed 1558 patients. ${ }^{85}$ Somewhat mysteriously, between 8 June 1940 and 3 June 1941 the Lange Commando ceased killing Poles with disabilities. ${ }^{86}$ Nonetheless, in terms of the broader picture, between the end of 1939 and the summer of 1941, T4 gassed at least 80,000 Germans $^{87}$ and thousands of Poles with disabilities. ${ }^{88}$ This gassing technique generated little strain, trauma, or repugnance on the perpetrators who neither had to touch, see, nor hear their victims die. In fact, should they have desired it, gassing offered the killers the option of total perceptual avoidance.

\section{The Transformation of Himmler and Heydrich}

Since early in 1939 when Heydrich had been charged with settling Germany's "Jewish problem," Himmler, his superior, fretted over the SS's repeated failure to resolve this issue. This concern came to a head in January 1941, when Himmler appealed directly to Heydrich for a solution to the problem of population exchange in the East between Jews, Christian Poles, and ethnic Germans. ${ }^{89}$ There was no obvious place yet available to send the Poles. Around this point in time, however, I would argue that Himmler and Heydrich underwent a gradual transformation. That is, across the period that their own more "realistic" policy of emigration faltered, moderately antisemitic Germans demonstrated an uncanny ability to eliminate fairly large numbers of defenseless civilians. It did not take long for Himmler and Heydrich to sense potential in previously rejected ideas of the "strong believers."

The emergence of this transformation perhaps traces back to the summer of 1940 when Himmler confirmed his "realist" status when he said, "'out of inner conviction,' he still rejected 'the physical extermination of a race through Bolshevik methods...[because they were] un-Germanic 
and impracticable." "90 In other words, it was beneath the dignity of Germans to engage in acts of mass killing. Simultaneously, Heydrich parroted the same argument. ${ }^{91}$ And in any case, because such ideas were considered "impracticable," they were ruled out from further discussion. However, as Himmler implied, if extermination suddenly became feasible, he might be willing to reconsider.

So, it is clear that much like their Führer, Himmler and Heydrich only favored emigration over more radical "strong believer" measures because the former seemed more "realistic." Thus, for "realists" like Hitler, Himmler, and Heydrich, the desire to exterminate "inferiors" had always been present ${ }^{92}$ - keeping in mind that their preference to cram Jews into cargo ships and deport them to Madagascar's harsh tropical environment (perhaps governed by T4's Philipp Bouhler) ${ }^{93}$ was, in itself, inherently genocidal. ${ }^{94}$ However, before 1941 a realistic means of achieving largescale extermination did not exist. Hitler may have repeatedly hinted at his "wish" that the Jews be exterminated, but before 1941 all signals indicated that converting such a desire into reality was probably impossible. ${ }^{95}$ The impracticality of a "Final Solution" before 1941 helps to explain why there was no planning for genocide before then. ${ }^{96}$

But as the previously unrealistic ideas of the "strong believers" began showing greater potential than their own stalled "realist" strategies, both Himmler and Heydrich started contemplating ways of applying "strong believer" solutions to local manifestations of the "Jewish problem." For example, sometime after October or November of 1940, the Chief SS physician, Ernst Grawitz, claimed that Heydrich asked him to boost the death rate in the Warsaw ghetto by triggering an epidemic. ${ }^{97}$ More certainly, a few months later Himmler contemplated using the T4 euthanasia gassing technique in his over-crowded concentration camps. In a discussion in early 1941 between Himmler and Bouhler about prisoners no longer capable of productive labor, the SS-Reichsführer wondered, "whether and how the personnel and the facilities of T4 can be utilized for the concentration camps." 98

Early in 1941, T4 leader Bouhler agreed to let Himmler use T4 personnel and facilities to rid the camps of 'excess' prisoners - notably those 'most seriously ill,' physically and mentally. Sometimes called 'prisoner euthanasia' or (by prisoners) 'Operation Invalid,' the resultant program was officially 'Operation [or Special Treatment] 14f13.'99 
The 14fl3 killing program started in April $1941^{100}$ and was soon after extended to the recently built concentration camps in the East. By the end of May ${ }^{101}$ or July ${ }^{102}$ of 1941 , ex-T4 personnel working in Operation $14 \mathrm{fl} 3 \mathrm{had}$ arrived in the hinterlands of Poland, in places like Auschwitz I. In a related operation, 575 men from Auschwitz I who "were all worn out" 103 were selected and transported by train to a T4 gas chamber hundreds of miles away at Sonnenstein in Germany. ${ }^{104}$ German camp officials determined that these men could not be killed at Auschwitz I without causing a commotion. ${ }^{105}$ By the end of the war, Operation $14 \mathrm{fl} 3$ had killed nearly 20,000 people. ${ }^{106}$

Himmler and Heydrich, of course, were not the only ones to sense potential in the ideas of the strong believers. Consider, for example, Rudolf Gater, a rationalization expert, who independently saw merit in ghetto administrator Palfinger's intuition when in March of 1941 he argued that, "conditions of undernourishment" in the Polish ghettos "could be allowed to develop without regard for the consequences."107 Also, on 16 July 1941 SS-Sturmbannführer Rolf-Heinz Höppner wrote in a letter to Eichmann,

This winter [in the Wartheland] there is a danger that it will not be possible to feed all the Jews. It should therefore seriously be considered whether the most humane solution would not be to eliminate those Jews unfit for work by some fast-working method. That would in any case be more agreeable than leaving them to die of starvation. ${ }^{108}$

He concluded, "These things sound somewhat fantastic but are in my opinion definitely feasible." 109 Curiously, during the four-week period before Höppner wrote this letter, the Lange Commando had resumed, after their 12-month hiatus, exterminating Wartheland Poles with disabilities. ${ }^{110}$ Perhaps Höppner was cognizant of Lange's activities (both were based in Poznań), ${ }^{111}$ and maybe this explains why, with respect to the Jews, he had euthanasia gassing technology in mind. ${ }^{12}$ However, Himmler, who two months earlier had sent hundreds of Auschwitz's prisoners by train to be gassed in Germany, had already discovered that installing the T4 killing technology in the Eastern territories was actually impracticable. It was impracticable because gassing required cylinders of pure carbon monoxide which were expensive to produce, difficult to transport out of Germany, and the quantities required to kill such large numbers of civilians simply did not exist. ${ }^{113}$ If gassing was ever to 
be relied upon in the East, all of these obstacles would have to be overcome. As Hilberg argued,

We are dealing not with a sudden decision but with the emergence of an idea. [...] the idea of killing the Jews had now matured. As a plan for administrative action, the idea was not yet obvious or even feasible; but as a thought of something that could happen. ${ }^{114}$

But only those in direct control of the machinery of destructionHimmler, "a genius for organization"115 and the "Architect of Genocide," 116 and Heydrich, "the real engineer" (as Gerald Reitinger called him ${ }^{117}$ )—were in sufficiently powerful positions to convert such ideas into reality. ${ }^{118}$ As both the "Realization of the Unthinkable"119 simmered and Hitler started unveiling his intentions to invade the Soviet Union, "Murder" as Browning observes "was in the air..."120

\section{Hitler And The Invasion of The Soviet Union}

With a handful of successful military campaigns and most of Western Europe under his belt in December 1940, a Hitler brimming with confidence finalized his plans to attack the Soviet Union. Termed Operation Barbarossa, the campaign was to start the following summer. ${ }^{121}$ Like the invasion of Poland, Operation Barbarossa would be a two-pronged assault. The Wehrmacht would lead the way, deploying its trademark Blitzkrieg tactics. Himmler's men would follow in the German military's wake and secure the captured territory. Again, the Nazi leadership suspected that Russia's so-called Jewish-Bolshevik intelligentsia would encourage common folk to resist German forces, and so on 13 March 1941, Hitler tasked Himmler's SS with the elimination of these leaders. ${ }^{122}$ On 26 March, Eduard Wagner (the Quartermaster General of the Wehrmacht High Command) and Himmler agreed with this general plan. ${ }^{123}$ A few days later on 30 March, Hitler informed a couple of hundred commanding officers that during Operation Barbarossa they were not to rely on traditional military customs. Instead, this was a,

Clash between two ideologies... Bolshevism equals a social criminality. Communism [is a] tremendous danger for the future. We must get away from the standpoint of soldierly comradeship. The Communist is no comrade, either before or after. It is a war of extermination $[. .$.$] The troops$ 
must defend themselves with the methods with which they are attacked. Commissars and secret service personnel are criminals and must be treated as such. [italics added] $]^{124}$

If one reads a little between the lines here, because the Nazis closely associated Jews with Bolshevism, here Hitler was socially constructing the Jews-or at least the (apparent) Jewish Soviet leadership-into a population of criminals. And because, according to the dictates of Nazi ideology, Jews are genetically immutable, the only infallible and permanent means of eliminating this omnipotent crime problem was that it be exterminated. Hitler urging his commanders to exterminate Bolshevist Jews may sound like an extremely radical request, but it should be kept in mind that before unification, Germany's many states had long histories of killing those deemed by rule-making legislators to be "dangerous criminals." Interestingly, just over a year earlier in the November 1938 edition of Das Schwarze Korps, Heydrich explicitly captured what I suspect was the Führer's attempt at framing all Jews as "criminals..." On top of this, the SS-Obergruppenführer also makes the normative connection to what Germans had historically done with such people.

The German people are not in the least inclined to tolerate in their country hundreds of thousands of criminals, who not only secure their existence through crime, but also want to exact revenge. [...] These hundreds of thousands of impoverished Jews [would create] a breeding ground for Bolshevism and a collection of the politically criminal subhuman elements. [...] In such a situation we would be faced with the hard necessity of exterminating the Jewish underworld in the same way as, under our government of law and order, we are accustomed to exterminating any other criminals - that is, by fire and sword. The result would be the actual and final end of Jewry in Germany, its absolute annihilation. ${ }^{125}$

Again, Bolshevists were Jews, Jews were criminals, and, as long practiced throughout German history, it was quite normal for the government to execute those deemed by rule makers to be dangerous criminals. For many Germans in the armed forces, this was just the kind of reasoning that helped personally legitimize their killing of a large category of other human beings.

Putting aside the Nazi's gradual social construction of Jews into "criminals," it was Hitler's suspicion that a successful invasion of the Soviet Union would have many benefits for Germany. It would surely force 
Britain to concede defeat. If not, however, the Nazis would gain access to the fertile Ukrainian breadbasket, thus circumventing the effectiveness of any Allied blockade of the German civilian population, such as had occurred during World War One. ${ }^{126}$ The Nazis might also gain access to the Caucasus oil fields, the largest in Europe. ${ }^{127}$ And finally, a Soviet defeat might discourage the Americans from entering the war. Tainting any such anticipated victory, however, were the four or perhaps five million Jews living within the Soviet Union's post-August 1939 borders. ${ }^{128}$ Himmler and Heydrich, charged with resolving the Jewish problem, would have been particularly sensitive to this drawback. Then again, a successful conquest of Russia might (with the British Navy presumably out of the way) revive the Madagascar Plan as a potential solution to the "Jewish Question," and if not, the massive Soviet interior included several new possible expulsion sites (presumably viewed to be German colonial penal colonies), including the Ukrainian marshlands or even the Siberian wastelands. ${ }^{129}$

In preparation for eliminating the Soviet intelligentsia, about 3000 rank and file men drawn from the SS, SD, the Gestapo, Sipo, Waffen SS forces, as well as the less politicized State Police, Reserve Police Battalions, and also some civilian draftees were recruited for special training in May 1941. ${ }^{130}$ The men were divided into four groups: Einsatzgruppe A, B, C, and D. These four groups were further subdivided into units called Einsatzkommandos (50-175 men each), and further again into Sonderkommandos. ${ }^{131}$ Also, a month earlier, around mid-April, Himmler instructed Police Battalion 322, and probably other police units, to prepare for operations outside of Germany. ${ }^{132}$

One interpretation of the Nazi regime's attack on the Soviet Union is that just before the start of the campaign, Himmler and Heydrich were so concerned about their ever-expanding "Jewish problem" that they subtly conveyed their ultimate desire to the commanders tasked with executing the "Jewish-Bolshevik intelligentsia" that they wanted their execution squads to exterminate every Jewish man, woman, and child encountered. As Breitman notes: "One reading of the events is that the Einsatzgruppen commanders already knew the final goal of Nazi Jewish policy and were given some discretion to accomplish as much as they could with limited manpower." 133 This is not to suggest that before the start of the invasion execution squad commanders were given direct orders to exterminate Soviet Jewry (a controversial issue termed the Krausnick versus Streim debate), ${ }^{134}$ but rather that the commanders of the execution squads had a "vague notion" 135 of what Himmler and 
Heydrich desired of them: They were to exterminate as many Jews as they possibly could.

The main reason I suspect there were no direct orders instructing all Jews to be killed is that before the campaign both Himmler and Heydrich were not sure their men would be willing and/or capable of fulfilling such orders. As Jürgen Matthäus puts it, "Before the unleashing of Operation Barbarossa, the German leadership could not be certain that its political will would be carried out in the field."136 Much of the SS leadership's skepticism came from the earlier Polish campaign during which German armed forces were ordered to shoot civilians. Although the Germans killed tens of thousands, they frequently experienced "vast agitation and powerful emotional stress" from doing so. Himmler's awareness of these psychological problems was so acute that in June 1940 he employed and promoted the brutal World War One veteran Oskar Dirlewanger (also a convicted pedophile) and supplied him with a battalion of ex-convict poachers-killing specialists-for the kinds of human shooting assignments that Himmler suspected most Germans would shy away from. ${ }^{137}$ But the task of eliminating just the Russian intelligentsia was so great that Himmler and Heydrich needed to rely on more numerous categories of Germans from the SS, Order Police, and Wehrmacht.

On the other hand, Himmler and Heydrich may have had reason to suspect that their ordinary men might be willing and capable of killing every Soviet Jew encountered given the right circumstances. During the Polish campaign, some members of the execution squads proved themselves entirely capable of regularly shooting defenseless men ${ }^{138}$ - a difficult task some perceived as a measure of manliness. ${ }^{139}$ This time the victims would not be somewhat similar-looking Poles, but Soviet Jews, people who were ethnically, culturally, and economically significantly different from the Germans who filled Himmler's ranks. Furthermore, Soviet Jews embodied the two main targets of nearly a decade of Nazi propaganda-the threat of "Jewish Bolshevism." On top of this, with some of his men having willingly executed many Poles accused of partisan resistance, it is perhaps of little surprise that with increasing intensity after the Polish invasion, Himmler liked to remind his men that "Where there are partisans...there are Jews, and where there are Jews, there are partisans." 140 Because Himmler later came to believe that the word "partisan" tended to glamorize Bolshevism, in a special order he 
then requested the application of this word be replaced with "bandits," "franc-tireurs," and-in line with Hitler's own term- "criminals..."141

Importantly, because during the lead-up to the Soviet invasion the Nazi regime had socially constructed Jews to be both "partisans" and "criminals," Himmler and Heydrich likely suspected that the killing of all Jews - unlike during the start of the Polish campaign - might have been within the German armed force's Zone of Indifference. More specifically, because the role of soldiers and police officers occasionally involves killing "criminals" and "partisans" (respectively), the annihilation of all Jews was now a task that, with less reservation, they might-if psychologically capable-willingly partake. And even if armed Germans proved psychologically incapable of killing all Jewish civilians in the East, perhaps more fiercely antisemitic Eastern European collaborators might do the job.

Whether German or Eastern European executioners succeeded or not in killing every Jewish person encountered, the end result would still be fewer Jews contributing to Himmler and Heydrich's escalating "Jewish problem."142 If their subtle plans resulted in a technically feasible solution, they could then invest far more resources into it. And if the plan failed dismally, and all available forces flatly refused to participate in something as unethical and unlawful as genocide, the SS leadership - including Hitler - could plausibly deny the existence of any such order (perhaps explaining why no direct orders to kill all Jews before the Soviet invasion have ever been found). ${ }^{143}$ It will be recalled that just before the Polish invasion Hitler had boasted to his commanders of sending "my 'Death's Head Units' with the order to kill without pity or mercy all men, women, and children of Polish race or language." He must have felt a little embarrassed when they did no such thing, with some soldiers even suffering breakdowns when they tried to kill Polish civilians en masse. And perhaps it was here that a red-faced Hitler learned from his presumptuousness. As Henry Friedlander observed,

although Hitler believed that the cover of war would make radical exclusion through killing operations possible - which he emphasized by backdating his euthanasia authorization to the day the war began - he nevertheless did not issue a definite order [regarding the "Jewish problem"] until he was certain that such an ambitious killing enterprise was feasible. ${ }^{144}$ 
Again, before Hitler would back a "strong believer" solution, such a solution had to be "realistic." 145 And even if Himmler and Heydrich failed, because they left the door of plausible deniability wide open, they could evade the embarrassment that usually, when among their Nazi peers, accompanies such failure and simply move on to test some other more "realistic" strategy. And the Nazi leadership did have a history of issuing vague orders necessitating subordinate initiative, especially when those leaders wanted to retain the option of later denying responsibility for delivering those orders. ${ }^{146}$ Because Himmler and Heydrich were confident that Germany would win the war and would soon be in total control of all of Europe, suspecting they could act with impunity, they likely believed themselves to have a free hand to dabble in genocide. Somewhat like Milgram, they suspected that from positions of power they could determine what was morally right and wrong. Quite simply, the SS leadership suspected they had an enormous amount to gain and little to lose in running their pilot study in genocide-what Konrad Kwiet terms a "testing ground for subsequent killings." 147

Although Himmler and Heydrich were unsure if their men would kill every Jewish person they encountered, one variable they did control was their own actions. Having learned from their past experiences during the Polish campaign, from the top-down, they would do all they could to encourage, persuade, or, if necessary, coerce their men into doing what they ultimately desired. ${ }^{148}$ For example, during training for their future tasks, members of the Einsatzgruppen and Order Police were exposed to a deluge of antisemitic propaganda. ${ }^{149}$ Perhaps if the men had a strong ideological rationale for harming others, they might come to see the "necessity" of killing all Jews and associate the second part of their training schedule-shooting practice-as the means of achieving that end. ${ }^{150}$

Even though the rank and file was not selected on an individual basis, the same could not be said of their field commanders. Around mid-April 1941, Himmler started to personally select his Higher SS and Police leaders. ${ }^{151}$ And in terms of the Einsatzgruppen, not only were these commanders handpicked on the basis of initiative and independence ${ }^{152}$ but also nearly all of them possessed characteristics that reinforced the perception that they were credible and intellectual elites. As Müller-Hill observes, of the fifteen commanders in the Soviet interior between 1941 and 1943, six (40\%) had doctoral degrees, and three others $(20 \%)$ had studied law. ${ }^{153}$ Furthermore, 16 of 69 (23\%) Einsatzkommando leaders held doctoral degrees, with the remainder having at least studied 
at university. ${ }^{154}$ Officers were likely to have been educated at prestigious German or Austrian universities and often worked in the law profession. ${ }^{155}$ This was no coincidence: If there was a threat that the lower ranks might baulk at the legalities of exterminating certain categories of civilians, the binding force of uncompromising ideologues whose expertize frequently lay in the law itself might mitigate this risk. If they were not lawyers, the field commanders typically came from other respected professions-the kind of high-status positions (like Dr. Milgram or Williams the Yale-based "scientist") a reluctant subordinate could conveniently place their faith in. Drawing on Müller-Hill's research, as Hilary Earl notes: "When a university professor, an economist, a priest, a doctor, or a lawyer order executions, "they cannot be wrong..."'156

Despite carefully selecting the leadership class and then barraging the rank and file with ideological propaganda and training with weapons fairly low in perceptual stimulation, a few days before the launch of Operation Barbarossa, Heydrich expressed doubts about the willingness and/or capability of his men to shoot civilians. With the intention of passing off such dirty work to local populations, Browning argues that Heydrich stressed in a meeting with the Einsatzgruppen commanders in Berlin on 17 June that, "No obstacle was to be placed in the way of the 'self-cleansing efforts'... of anticommunist and anti-Jewish circles."157 With respect to the German men's capacity to exterminate civilians, Matthäus argues the SS leader had a "fear of going too far too quickly," and (with a hint of the foot-in-the-door phenomenon) "instead of providing explicit orders for the rapid expansion of the killing process, the SS and police leadership in Berlin seems to have followed a course that can be described as controlled escalation." 158 According to Breitman, Himmler likewise believed "Once they [his men] had carried out mass murder in response to an alleged crime or provocation, it would be easier to get them to follow broader killing orders later." 159

On the eve of the attack, the German armed forces issued the rank and file with the (purposefully ambiguous?) Commissar Order. The order stated, "This struggle demands ruthless and energetic measures against bolshevist agitators, guerrillas, saboteurs, Jews, and complete elimination of any active or passive resistance." 160 For groups such as the Einsatzgruppen, the Commissar Order was congruent with their main task: Much like during the Polish invasion, they were to secure the captured territory and kill any signs of national leadership. Having said that, with the help of their field commanders, it was up to the men 
to interpret what "ruthless and energetic measures" against "Jews" engaging in "active or passive resistance" meant. Some would guess correctly and be rewarded. Others would fail (perhaps purposefully) to implement the SS leadership's desired course. For them, clearer hintssecondhand or, if necessary, personally delivered oral orders-would be needed. True to Hitler's usual management style, ambiguous orders left the door of "personal initiative" wide open. ${ }^{161}$ With increasing clarity, time, and experience, the men in the field would be shouldered with resolving what, for the more ambitious among them, would become an intense competition to find the "one best way" of shooting civilians en masse. ${ }^{162}$ With words somewhat reminiscent of Milgram's pilot studies, as Browning put it: "What they were being asked to accomplish was at the time totally unprecedented. At this stage every step was uncharted, every policy an experiment, every action a trial run." $" 163$

\section{ConClusion}

Between the end of 1939 and halfway through 1941, realist Nazi bureaucrats spent much time and energy debating where they could resettle an ever-increasing number of Jews and other conquered peoples. While at the same time, ordinary and arguably moderately antisemitic non-Jewish Germans ${ }^{164}$ began demonstrating their ability to kill fairly large numbers of defenseless civilians using what became by the war's end the three common methods of shooting, starvation, and gassing. With the repeated failure of the apparently more "realistic" policy of emigration, the most powerful "realist" bureaucrats started to sense potential in the previously rejected ideas of the "strong believers." As the invasion of the Soviet Union approached, an excellent opportunity appeared to at least test the feasibility of this radical solution. But would their men shoot all Soviet Jews? As Breitman argues, Himmler, Heydrich, and Kurt Daluege (of the Order Police) "did not yet know how smoothly the killing process would work, which leaders and units would prove effective, and whether there would be significant resistance, including resistance from the policemen themselves." 165 Browning adds, "they did not know - indeed could not have known - if the plans they had been formulating would even work."166 Time would certainly tell. 


\section{Notes}

1. Rossino (2003, p. 13).

2. Rossino $(2003$, p. 65$)$.

3. Rossino (2003, pp. 90, 117-118, 129-130).

4. Rossino (2003, pp. 117-118).

5. Rossino (2003, pp. 99-101, 120).

6. Rutherford $(2007$, p. 60$)$.

7. Angrick and Klein (2009, pp. 176-177), Browning (2004, pp. 36-72), Cesarani (2004, pp. 82-83) and Rutherford (2007, pp. 63-132).

8. Browning (2004, pp. 40-42).

9. Quoted in Browning (2004, p. 26). See also Mommsen (1986, pp. 118-119).

10. Kershaw (2000, pp. 111-112) and Cesarani (2016, p. 262). See also Rutherford (2007, p. 117).

11. Browning (2004, pp. 81-82).

12. Quoted in Browning (2000, p. 14).

13. Quoted in Browning (2000, p. 70).

14. Kershaw (2000, p. 131).

15. Kershaw $(2000$, p. 116).

16. Aly $(2006$, p. 52$)$.

17. Aly (2006, pp. 146-148).

18. Aly (2006, p. 107).

19. Kühl $(2016$, p. 88).

20. Aly (2006, p. 324).

21. Aly (2006, p. 136).

22. Quoted in Aly (2006, p. 107).

23. Quoted in Aly (2006, p. 17).

24. Friedländer $(2007$, p. 130).

25. Rees $(2005$, p. 19).

26. van Pelt and Dwork (1996, p. 181).

27. Lasik (1998, p. 292).

28. van Pelt and Dwork (1996, p. 255).

29. Hilberg (1961b, p. 1011).

30. Levin and Fox $(1985$, p. 58$)$.

31. Eggers and Peters (1993, p. 199).

32. Rossino (2003, p. 129).

33. Quoted in Browning (2004, p. 74). See also Buchheim (1968, p. 317) and Headland (1992, p. 211).

34. Westermann (2005, p. 144). 
35. Grossman (1995, p. 112).

36. Roseman (2002, p. 24).

37. Rossino (2003, p. 234).

38. Browning $(2004$, p. 124).

39. The Lódź ghetto was sealed in April 1940 to promote the extraction of Jewish wealth in exchange for food, whereas the Warsaw ghetto was sealed in mid-November 1940 because of fears surrounding the possible spreading of disease and epidemics (Browning 1995, pp. 32-34).

40. Hayes $(2017$, p. 181$)$.

41. Rutherford (2007, p. 121).

42. Quoted in Mommsen (1997, p. 30).

43. Corni (2002, p. 205$)$.

44. Quoted in Browning (2004, p. 128; 1995, p. 36).

45. Browning (1995, p. 30).

46. Quoted in Browning (1995, p. 36).

47. Browning (1995, p. 36).

48. Hayes (2017, p. 181).

49. Quoted in Browning (2004, p. 125).

50. Quoted in Browning (1995, p. 39).

51. Quoted in Browning (1995, pp. 40-41).

52. Aly and Heim (2002, pp. 243-244).

53. Quoted in Aly and Heim (2002, p. 240).

54. Quoted in Browning (2004, p. 156).

55. Bauer (1982, p. 170).

56. Browning (1995, p. 47).

57. At a meeting on 19 April 1941, Frank argued: "That one cannot dissolve the ghetto and leave the Jews in freedom, over that there is still full agreement" (quoted in Browning 2004, p. 129). Having said that, with so little food entering the Warsaw ghetto, Browning has also pointed out that occasionally these German administrators still felt it was "necessary to tolerate gaps in the ghetto cordon” (2004, p. 130). For similar such behavior, see Langerbein (2004, p. 138).

58. Lanzmann (1995, p. 179). For an opposing example where "dead Jews" in the Warsaw ghetto "were becoming a sight not to be missed by German tourists," see Friedländer (2007, p. 160).

59. Hayes (2017, p. 180).

60. Quoted in Kühne $(2010$, p. 80). Then again, if the Jewish managers failed to perform their duties, the Germans had no qualms over entering a ghetto with devastating force, as they did in Lublin on 16 March 1942 or during the Warsaw ghetto uprising (Cesarani 2016, pp. 469, 613-617). 
61. Photos and film footage of conditions in the ghettos were frequently recorded and sent back to Germany, but these were only used for "educational" purposes to reinforce the Nazi regime's carefully manufactured antisemitic stereotypes and propaganda (Friedländer 2007, p. 38). One such example can be found in Abraham Lewin's diary, dated 19 May 1942: "Today" in the Warsaw ghetto the Nazi authorities "set up a film session in Szulc's restaurant. [...] They brought in Jews they had rounded up...sat them down at the tables and ordered that they be served with all kinds of food and drinks...meat, fish, liqueurs, white pastries and other delicacies. The Jews ate and the Germans filmed. It is not hard to imagine the motivation behind this. Let the world see the kind of paradise the Jews are living in" (quoted in Friedländer 2007, p. 394).

62. Lifton (1986, pp. 24, 27). See also Koonz (2003, p. 127).

63. Quoted in Friedlander (1995, p. 67).

64. Hayes $(2017$, p. 117).

65. Quoted in Russell $(2009$, p. 47).

66. See also Fritzsche (2008, p. 158, as cited in Stone 2010, pp. 75-76).

67. Quoted in Friedlander (1995, p. 86).

68. Friedlander $(1995$, p. 88$)$.

69. Friedlander (1995, pp. 86-87).

70. Montague (2012, p. 14).

71. Montague $(2012$, p. 16).

72. Montague (2012, p. 17).

73. Montague (2012, pp. 16, 18).

74. Montague (2012, pp. 18-19).

75. Montague (2012, pp. 19-20).

76. Montague (2012, p. 21).

77. Montague (2012, p. 22).

78. Montague (2012, p. 23).

79. Adam (1989, p. 136).

80. Quoted in Adam (1989, p. 136).

81. Adam (1989, p. 137).

82. Friedlander $(1995$, p. 87$)$.

83. Fleming (1984, p. 24).

84. Montague (2012, pp. 23-25, 28).

85. Browning $(1985$, p. 59$)$.

86. Montague (2012, pp. 29-30).

87. Friedlander (1995, pp. 109-110).

88. Rummel (1992, p. 13, as cited in Markusen and Kopf 1995, p. 131).

89. Cesarani $(2004$, p. 92$)$.

90. Fleming (1984, p. 44). 
91. During the summer of 1940 Heydrich argued, "The Jews are considered hostile to us because of our standpoint on race. For this reason they are of no use to us in the Reich. We must eliminate them. Biological extermination, however, is undignified for the German people as a civilized nation. Thus after the victory we will impose the condition on the enemy powers that the holds of their ships be used to transport the Jews along with their belongings to Madagascar or elsewhere" (quoted in Aly 1999, p. 3).

92. In the November 1938 edition of Das Schwarze Korps, Heydrich mentions his desire for the "absolute annihilation" of German Jewry (quoted in Breitman 1991, p. 58).

93. Longerich $(2010$, p. 164).

94. See Mommsen (1986, p. 120) and Browning (2004, pp. 88-89).

95. Following the Polish invasion in 1939, as Eduard Könekamp of the German Foreign Institute said in a report to his colleagues about the Jews: "Exterminating these subhumans would be in the best interests of the whole world. But exterminating them poses incredibly difficult problems. There are too many of them to shoot. And one can't simply shoot women and children. [...] But an effective solution to this complicated problem has yet to be found" (quoted in Aly and Heim 2002, p. 127).

96. Bauer $(2001$, p. 30$)$.

97. Breitman (1991, p. 139).

98. Quoted in Friedlander (1995, p. 142). Arad (1987, p. 9) suggests that Himmler made this request to Bouhler earlier, during "the summer of 1940..."

99. Lifton (1986, p. 135).

100. Hayes $(2017$, p. 119).

101. van Pelt and Dwork (1996, pp. 280-281).

102. Rees provides a slightly later date where " $14 \mathrm{fl} 3$...reached Auschwitz on July 28” (2005, p. 43). See also Cesarani (2016, p. 528).

103. This is according to Kazimierz Smoleń, a political prisoner at Auschwitz (Rees 2005, pp. 43-44).

104. van Pelt and Dwork (1996, pp. 280-281).

105. van Pelt and Dwork (1996, p. 280).

106. Lifton (1986, p. 142).

107. Quoted in Aly and Heim (2002, p. 180).

108. Quoted in Krakowski (1993, p. 74). During the first six months of the Soviet invasion conditions for Jews improved in the Polish ghettos because demand for manufactured goods increased within the Germany war economy (Cesarani 2016, pp. 433-435). Having said this, the poorest unemployed Jews still starved in the streets. 
109. Quoted in Browning (1985, p. 4).

110. Montague (2012, pp. 29-30).

111. See Longerich $(2010$, p. 264).

112. Browning (2004, p. 354).

113. Adam (1989, p. 139), Breitman (1991, p. 197), Browning (1985, p. 59), Fleming (1984, p. 48), Friedlander (1995, p. 286) and Specktor (1993, p. 52).

114. Hilberg (1961a, p. 257).

115. Cesarani (2016, p. 83).

116. Breitman (1991).

117. Arendt (1984, p. 36).

118. See Mommsen (1986, pp. 102, 114).

119. Mommsen (1986, pp. 122-126).

120. Browning (2004, p. 320).

121. Breitman $(2000$, p. 34$)$.

122. Browning (2004, p. 216).

123. Browning (2004, p. 217).

124. Quoted in Förster (1981, p. 13).

125. Quoted in Breitman (1991, p. 58).

126. Browning (2004, p. 238).

127. Cesarani $(2016$, p. 352$)$.

128. Hilberg (1992, p. 250) and Schleunes (1970, p. 256).

129. Aly and Heim (2002, p. 179) and Cesarani (2004, p. 92).

130. Browning (2004, p. 225) and Büchler (1986, p. 12).

131. MacLean $(1999$, p. 13$)$.

132. Breitman (2000, p. 45). See also Browning (2004, p. 233).

133. Breitman (2000, p. 44).

134. The Krausnick versus Streim debate is whether the execution squads were given direct orders just before the start of the war demanding that all Jews be killed (as Krausnick suspects), or just the men be killed, with women and children added as targets a few months later in August or September (as Streim suspects). There are limitations with both perspectives. The problem with Krausnick's theory is that a universal order before the start of Operation Barbarossa has never been found. But this weakness does not render Streim correct. As Longerich (2005, p. 214) argues: "While Krausnick's assumption of an early, universal annihilation order can clearly be disproved, we should, on the other hand, go further than Streim in emphasizing that the task allotted to the Einsatzgruppen, prior to 22 June, involved a mass murder whose limits were unclear. This order already contained within it the tendency towards total annihilation, and it was deliberately left up to the death squads themselves to decide what limits to place on the killings. Here we see a form of issuing 
of orders which relied upon interaction, fully in keeping with Nazi tradition." See the Krausnick versus Streim debate (Breitman 1991, p. 290).

135. Quoted in Matthäus (2007, p. 234).

136. Matthäus $(2007$, p. 220).

137. Breitman (1991, pp. 129-130).

138. Roseman (2002, p. 24) and Rossino (2003, p. 234).

139. Rossino (2003, p. 70$)$.

140. Manoschek (2002, p. 167, as cited in Kühl 2016, p. 144).

141. Quoted Brackmann and Berkenhauer (1988, p. 214, cited in Kühl 2016, p. 144). See also Longerich (2010, pp. 220, 289).

142. As Mommsen (1986, p. 122) argues, "The massacres also provided an opportunity to rid the German-occupied territories of a part of the Jewish population, which had by then increased beyond any 'manageable' size."

143. See Longerich (2005, p. 214).

144. Friedlander (1995, p. 286).

145. As Graml argues, the persecution of the Jews was about the "maturation" of "an essentially radical conviction..." "[A]s early as 1933" when, according to earlier threats, all German Jews were to be hung, neither "Hitler nor any other National Socialist would have been capable... of issuing the command for a mass murder of the Jews" (1991, p. 175, as cited in Stone 2010, p. 66).

146. Longerich (2010, pp. 204-205).

147. Kwiet (1998, p. 4).

148. See Longerich (2008, pp. 543-558, as cited in Stone 2010, p. 104).

149. Browning has pointed out that before the Soviet invasion, "Numerous materials were circulated among the police to provide the basis for these ideological training sessions" (2004, p. 232). The supply of this material increased as the campaign progressed (Westermann 2005, p. 109). See also Langerbein (2004, p. 19) and Heer (1997, pp. 89-90) for the Einsatzgruppen.

150. Units in the Order Police, like Battalion 322, for example, underwent similar ideological indoctrination and military training (Breitman 2000, p. 45$)$. See also Browning (2004, p. 232) and Kwiet (1993, p. 77).

151. Breitman (2000, p. 45$)$.

152. Bloxham and Kushner (2005, p. 137).

153. Müller-Hill (1996, p. 63).

154. Müller-Hill (1996, p. 63).

155. MacLean (1999, p. 144).

156. Earl (2009, p. 122).

157. Browning (2004, p. 228).

158. Matthäus (2004, p. 263). See also Longerich (2010, p. 219). 
159. Breitman (2000, p. 48$)$.

160. Quoted in Browning (2004, pp. 222-223).

161. Browning (2004, p. 242) and Longerich (1998, p. 417, as cited in Matthäus 2007, p. 234). The use of ambiguous orders that enable leaders to evade full responsibility for their men's destructive actions is not unique to the Nazis. According to one member of the US volunteer cavalry, just before the 1864 Sand Creek massacre in Colorado of mostly indigenous American women and children, Colonel John Chivington told his men "Boys, I shall not tell you what you are to kill, but remember our slaughtered women and children." This statement was verified by other members of the militia (Michno 2017, p. 62).

162. According to a witness during a 1962 court trial in Berlin, among the Einsatzgruppen shooting squads there was a "race for the highest numbers" of victims (as cited in Langerbein 2004, p. 59).

163. Browning (1995, p. 113).

164. To repeat Bauer's words “a high proportion of [Nazi] Party members were not extreme antisemites; rather, they shared an antisemitism that one could define as pervasive, yet not necessarily murderous, perhaps even "moderate" (2001, p. 31). Although these words are less likely to apply to the carefully selected shooting squad leaders, they are likely to have applicability to many of the rank and file executioners, who did not undergo individual selection for Operation Barbarossa.

165. Breitman (2000, pp. 44-45).

166. Browning (1995, p. 113).

\section{REFERENCES}

Adam, U. D. (1989). The gas chambers. In F. Furet (Ed.), Unanswered questions: Nazi Germany and the genocide of the Jews (pp. 134-154). New York: Schocken Books.

Aly, G. (1999). Final solution: Nazi population policy and the murder of the European Jews. London: Arnold.

Aly, G. (2006). Hitler's beneficiaries: Plunder, racial war, and the Nazi welfare state. New York: Metropolitan Books, Henry Holt and Company.

Aly, G., \& Heim, S. (2002). Architects of annibilation: Auschwitz and the logic of destruction. London: Weidenfeld \& Nicolson.

Angrick, A., \& Klein, P. (2009). The "final solution" in Riga: Exploitation and annibilation, 1941-1944. New York: Berghahn Books.

Arad, Y. B. (1987). Belzec, Sobibor, Treblinka: The Operation Reinhard death camps. Bloomington: Indiana University Press.

Arendt, H. (1984). Eichmann in Jerusalem: A report on the banality of evil. New York: Penguin. 
Bauer, Y. (1982). A history of the Holocaust. New York: Franklin Watts.

Bauer, Y. (2001). Rethinking the Holocaust. New Haven, CT: Yale University Press.

Bloxham, D., \& Kushner, T. (2005). The Holocaust: Critical historical approaches. Manchester, UK: Manchester University Press.

Breitman, R. (1991). The architect of genocide: Himmler and the final solution. New York: Alfred A. Knopf.

Breitman, R. (2000). Official secrets: What the Nazis planned, what the British and Americans knew. London: Penguin Books.

Browning, C. R. (1985). Fateful months: Essays on the emergence of the final solution. New York: Holmes and Meier.

Browning, C. R. (1995). The path to genocide: Essays on launching the final solution. New York: Cambridge University Press.

Browning, C. R. (2000). Nazi policy, Jewish workers, German killers. New York: Cambridge University Press.

Browning, C. R. (2004). The origins of the final solution: The evolution of Nazi Jewish policy, September 1939-March 1942. Lincoln: University of Nebraska Press.

Buchheim, H. (1968). Command and compliance. In H. Krausnick, H. Buchheim, M. Broszat, \& H. A. Jacobsen (Eds.), Anatomy of the SS state (pp. 303-396). London: Collins.

Büchler, Y. (1986). Kommandostab Reichsführer-SS: Himmler's personal murder brigades in 1941. Holocaust and Genocide Studies, 1(1), 11-25.

Cesarani, D. (2004). Eichmann: His life and crimes. London: William Heinemann.

Cesarani, D. (2016). Final solution: The fate of the Jews 1933-1949. London: Macmillan.

Corni, G. (2002). Hitler's ghettos: Voices from a beleaguered society 1939-1944. London: Arnold.

Earl, H. C. (2009). The Nuremberg SS-Einsatzgruppen trial, 1945-1958: Atrocity, law, and history. Cambridge, UK: Cambridge University Press.

Egger, S., \& Peters, R. (1993). Firearms law reform: The limitations of the national approach. In H. Strang \& S. Gerull (Eds.), Homicide: Patterns, prevention and control: Conference proceedings (pp. 197-204). Canberra, ACT: Australian Institute of Criminology.

Fleming, G. (1984). Hitler and the final solution. Berkeley, CA: University of California Press.

Förster, J. (1981). The Wehrmacht and the war of extermination against the Soviet Union. Yad Vashem Studies, 14, 7-34.

Friedlander, H. (1995). The origins of Nazi genocide: From euthanasia to the final solution. Chapel Hill: University of North Carolina Press. 
Friedländer, S. (2007). The years of extermination: Nazi Germany and the Jews, 1939-1945. New York: Harper Perennial.

Grossman, D. (1995). On killing: The psychological cost of learning to kill in war and society. Boston: Little Brown.

Hayes, P. (2017). Why? Explaining the Holocaust. New York: W. W. Norton.

Headland, R. (1992). Messages of murder: A study of the reports of the Einsatzgruppen of the security police and the security service, 1941-1943. London: Associated University Press.

Heer, H. (1997). Killing fields: The Wehrmacht and the Holocaust in Belorussia, 1941-1942. Holocaust and Genocide Studies, 11(1), 79-101.

Hilberg, R. (1961a). The destruction of the European Jews. Chicago: Quadrangle Books.

Hilberg, R. (1961b). The destruction of the European Jews (Vols. 1-3). New York: Holmes \& Meier.

Hilberg, R. (1992). Perpetrators, victims, bystanders: The Jewish catastrophe, 1933-1945. New York: HarperCollins.

Kershaw, I. (2000). The Nazi dictatorship: Problems and perspectives of interpretation (2nd ed.). London: Arnold.

Koonz, C. (2003). The Nazi conscience. London: The Belknap Press of Harvard University Press.

Krakowski, S. (1993). The stationary gas vans at Kulmhof. In E. Kogon, H. Langbein, \& A. Rückerl (Eds.), Nazi mass murder: A documentary history of the use of poison gas (pp. 73-101). New Haven, CT: Yale University Press.

Kühl, S. (2016). Ordinary organizations: Why normal men carried out the Holocaust. Cambridge, UK: Polity Press.

Kühne, T. (2010). Belonging and genocide. New Haven: Yale University Press.

Kwiet, K. (1993). From the diary of a killing unit. In J. Milfull (Ed.), Why Germany? National socialist anti-semitism and the European context (pp. 73-90). Oxford, UK: Berg Publishers.

Kwiet, K. (1998). Rehearsing for murder: The beginning of the final solution in Lithuania in June 1941. Holocaust and Genocide Studies, 12(1), 3-26.

Langerbein, H. (2004). Hitler's death squads: The logic of mass murder. College Station: Texas A\&M University Press.

Lanzmann, C. (1995). Shoah: The complete text of the acclaimed Holocaust film. New York: Da Capo Press.

Lasik, A. (1998). Rudolf Höss: Manager of crime. In Y. Gutman \& M. Berenbaum (Eds.), Anatomy of the Auschwitz death camp (pp. 288-300). Bloomington: Indiana University Press.

Levin, J., \& Fox, J. A. (1985). Mass murder: America's growing menace. New York: Plenum Press.

Lifton, R. J. (1986). The Nazi doctors: Medical killing and the psychology of genocide. New York: Basic Books. 
Longerich, P. (2005). From mass murder to the "final solution": The shooting of Jewish civilians during the first months of the Eastern campaign within the context of the Nazi Jewish genocide. In S. Gigliotti \& B. Lang (Eds.), The Holocaust: A reader (pp. 198-219). Oxford, UK: Blackwell.

Longerich, P. (2010). Holocaust: The Nazi persecution and murder of the Jews. Oxford, UK: Oxford University Press.

MacLean, F. L. (1999). The field men: The SS officers who led the Einsatzkommandos-The Nazi mobile killing units. Atglen, PA: Schiffer Military History.

Markusen, E., \& Kopf, D. (1995). The Holocaust and strategic bombing: Genocide and total war in the twentieth century. Boulder, CO: Westview Press.

Matthäus, J. (2004). Operation Barbarossa and the onset of the Holocaust, June-December 1941. In C. R. Browning (Ed.), The origins of the final solution: The evolution of Nazi Jewish policy, September 1939-March 1942 (pp. 248-308). Lincoln: University of Nebraska Press.

Matthäus, J. (2007). Controlled escalation: Himmler's men in the summer of 1941 and the Holocaust in the occupied Soviet territories. Holocaust and Genocide Studies, 21(2), 218-242.

Michno, G. (2017). The three battles of Sand Creek: The Cheyenne Massacre in blood, in court, and as the end of history. El Dorado Hills, CA: Savas Beatie.

Mommsen, H. (1986). The realization of the unthinkable: The 'final solution of the Jewish question' in the Third Reich. In G. Hirschfeld (Ed.), The policies of genocide: Jews and Soviet prisoners of war in Nazi Germany (pp. 97-144). London: Allan \& Unwin.

Mommsen, H. (1997). There was no Führer order. In D. L. Niewyk (Ed.), The Holocaust: Problems and perspectives of interpretation (2nd ed., pp. 27-38). New York: Houghton Mifflin.

Montague, P. (2012). Chetmno and the Holocaust: The history of Hitler's first death camp. London: I.B. Tauris.

Müller-Hill, B. (1996). The idea of the final solution and the role of experts. In D. Cesarani (Ed.), The final solution: Origins and implementation (pp. 62-72). New York: Routledge.

Rees, L. (2005). Auschwitz: A new history. New York: BBC Books.

Roseman, M. (2002). The villa, the lake, the meeting: Wannsee and the final solution. London: Penguin Press.

Rossino, A. (2003). Hitler strikes Poland: Blitzkrieg, ideology, and atrocity. Lawrence: University Press of Kansas.

Russell, N. J. C. (2009). Stanley Milgram's obedience to authority experiments: Towards an understanding of their relevance in explaining aspects of the Nazi Holocaust. Unpublished doctoral thesis, Victoria University of Wellington, New Zealand. 
Rutherford, P. T. (2007). Prelude to the final solution. Lawrence: University of Kansas.

Schleunes, K. A. (1970). The twisted road to Auschwitz: Nazi policy toward German Jews, 1933-1939. Chicago: University of Illinois Press.

Specktor, S. (1993). Killing in the gas vans behind the front. In E. Kogon, H. Langbein, \& A. Rückerl (Eds.), Nazi mass murder: A documentary history of the use of poison gas (pp. 52-72). New Haven, CT: Yale University Press.

Stone, D. (2010). Histories of the Holocaust. Oxford, UK: Oxford University Press.

van Pelt, R. J., \& Dwork, D. (1996). Auschwitz: 1270 to the present. New York: W. W. Norton.

Westermann, E. B. (2005). Hitler's police battalions: Enforcing racial war in the east. Lawrence: University Press of Kansas.

Open Access This chapter is licensed under the terms of the Creative Commons Attribution 4.0 International License (http://creativecommons.org/licenses/ by $/ 4.0 /$ ), which permits use, sharing, adaptation, distribution and reproduction in any medium or format, as long as you give appropriate credit to the original author(s) and the source, provide a link to the Creative Commons licence and indicate if changes were made.

The images or other third party material in this chapter are included in the chapter's Creative Commons licence, unless indicated otherwise in a credit line to the material. If material is not included in the chapter's Creative Commons licence and your intended use is not permitted by statutory regulation or exceeds the permitted use, you will need to obtain permission directly from the copyright holder.

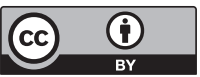

